Prof. Geikie's able lecture on geographical evolution is promised for the June number.

WE understand that, chiefly through the instrumentality of a veteran Arctic officer, the Council of the Royal Geographical Society were some time back induced to urge upon H.M. Government the propriety of despatching a vessel to the relief of Prof. Nordenskjold early in the present season. The matter, of course, was referred to the Admiralty, and "My Lords," after mature deliberation, have arrived at the conclusion that the matter had better be left to private enterprise. This resolution may be looked upon as a tolerably sure indication that the present Government are not disposed to embark upon an Arctic expedition of any description.

WE hear that Mr. Keith Johnston, the leader of the Geographical Society's East African Expedition, was to leave Zanzibar at the end of last month for Dar-es-Salaam, on the mainland, with the view of making final preparations for his journey to Lake Nyassa. The fact of his having been fortunate enough to secure the services of Chuma, Livingstone's old follower, will, no doubt, smooth away many difficulties, which otherwise would have caused him much trouble. Mr. Johnston has, we believe, turned his somewhat lengthy stay at Zanzibar to good account in the accumulation of all the information that could be procured respecting the tribes through which he will have to pass; and in this matter he has received very great assistance from an Arab named Bushire bin Selim, who is acquainted with some part of the country between the coast and Lake Nyassa, and who states that, though there is no direct road from the coast, the region at the north end of the lake is regularly visited by branch routes from the main road between Bagamoyo and Ujiji.

M. DE SEMELLÉ, whose death was we are glad to say prematurely announced, has succeeded in ascending the Niger and the Binué as far as Okeri, a point, it is stated, which has not hitherto been explored. He has collected valuable information on the products of the country, and the history and traditions of the people. He intends meantime to return to France for further subsidies to enable him to continue his exploration. M. Soleillet, who had to return to St. Louis in Senegal, after reaching Segou, is to set out on a new expedition for "Tichid, Wallatana, Timbuctoo, the Touat, and Algiers." M. Soleillet has brought back much interesting information concerning the people among whom he has been travelling, and of whom he speaks in very high terms for their intelligence and culture.

M. SAVORGNAN DE BRAZZA is about to set out for further exploration in the Ogowe region; he will endeavour to penetrate to the interior by the Alima and the river into which it falls.

IN No. 4 of the Mittheilungen of the Vienna Geographical Society, Count Stefanovic von Vilovo discusses the causes of the recent disastrous floods at Szegedin. Five years ago, it seems, he prophesied that some such catastrophe must happen, but he was only laughed at. He showed that this would be caused by the damming back of the water in the narrow rocky passes at Plocsa, and in the Kazan, in the narrow pass between Bazian and the Iron Gates, the surplus water being thus forced back into the nearest tributaries, the Morava, the Temes, the Save, and above all the Theiss. He maintains that the present disasters are solely 'the work of those rocks at Plocsa and in the Kazan, preventing the carrying off of the unusual quantity of water thrown into the river by the rains and snows of last autumn. Dr. Holub's paper on the Marutse-Mambunda is continued, with many illustrations and vocabularies, as also the papers of Prof. Benoni, on the sources of the Dniester, and Hesse-Wartegg's, on the river-bed of the Mississippi. Herr von Hochstetter contributes an illustrated paper on the magic instruments of the rain-maker among the natives of Inner Australia.
A LETTER from Herr Déchy, dated Darjeeling, March 9, in the Mittheilungen of the Vienna Society, states that in a day or two he expected to leave with a well-equipped expedition for exploration in Western Sikkim. He was to go through the valley of the Great Runget to the south foot of Kinchingunga; thence, climbing the PundimNursing ridge into the Testa Valley, he vas to explore the valleys, mountains, and passes of the Thlonok and Zemu rivers. Herr Déchy expects to add much to our imperfect knowledge of these regions, and his expedition is well supplied with instruments for scientific observation.

THE new number of Les Annales de l'Extrême Orient, which is doing good service by its translations of the accounts of Dutch explorations in Oceania, \&c., contains remarks by $H$. von Rosenberg on the Schouten Islands at the entrance to Geelvink Bay, New Guinea, and bries notes by $M$. van Hasselt on Alahan-Pandjang in Sumatra, accompanied by a map. This periodical, it may be mentioned, records the proceedings of the Societé Académique Indo-Chinoise.

WE understand that Prof. P. J. Veth, of Leyden, the learned president of the Geographical Society of the Netherlands, has been elected an honorary corresponding member of the Royal Geographical Society.

WE learn from the Colonies and India that a very interesting operation has been performed in the Thames River, New Zealand, viz., the blowing up of the Awotonga Falls, near the Awoka mountain. They were 75 miles from the mouth of the river, and had been a great hindrance to navigation. The falls were blown up with 200 lbs. of dynamite, the column of water rising to a height of 470 feet, and forming a magnificent spectacle. In addi tion to these falls, there have been removed in a similar manner several dangerous and impassable rapids and up wards of 500 "snags," varying from two to eight feet in diameter, and some of them I 20 feet long. The clearing of this river, it is said, will open up a million acres of excellent land, which the Government have obtained from the natives.

\section{TRENHAM REEKS}

WITH much regret we record the death of Mr. Trenham Reeks, the esteemed Registrar of the Royal School of Mines, Jermyn Street. He had been ailing for some weeks, and last week the complaint assumed the serious form of inflammation of the lungs. There was still hope of his recovery a few days ago, but he expired on Tuesday morning, the 5 th inst. By his death one of the oldest associations of the Geological Survey and School of Mines is severed. While still young he became connected with the infant museum established by the energy of his friend, Sir Henry de la Beche, in Craig's Court ; and on the enlargement of that establishment and the creation of the School of Mines, he was appointed to the office which he has held up till now. Having in early life devoted himself to chemistry and mineralogy, he took great pride in the mineralogical collection under his charge in Jermyn Street, and from year to year enriched it with fresh acquisitions. He had a great knowledge of pottery, and gained it at a time when the taste was far less general than it is now. The illustrated hand-book which, in conjunction with De la Beche, he prepared of the ceramic collection in the Jermyn Street Museum, though long ago out of print, is still a valued work of reference. Personally, he was singularly courteous and obliging, though tenacious of purpose and not easily defeated in any matter wherein he had resolved to succeed. He thoroughly identified himself with the interests of the School of Mines, to which his loss must now be great.

Not a few who read these lines will long remember the 
little, rather dingy, room in which, for well nigh thirty years, he has sat amidst blue-books, calendars, mineralogical specimens, and a rather orderly chaos of miscellaneous objects. They will think with sadness of the rupture of these old associations, and will follow to the grave with deep respect and sincere regret the old friend who has been so suddenly and unexpectedly removed from their midst.

\section{WILLIAM GEORGE VALENTIN}

$\mathrm{T} T$ is with much regret that we record the untimely and sudden death on the Ist inst. from apoplexy of Mr. William George Valentin. He was born in Neuenburg, in the Black Forest, on May I6, 1829. He came to England in 1855 , and, in the early days of the Royal College of Chemistry, studied under Dr. Hofmann, who esteemed him greatly, and, recognising his ability, made him senior assistant in the laboratory, a position which he retained at the Science Schools, South Kensington, under Dr. Frankland. He held for some years the office of gas examiner to the Great Western Gas Company, and at the time of his death was chemical adviser to the Trinity House.

His chemical text-books are deservedly popular; and within the last few days he corrected the final proofs of a new work which is therefore nearly ready for publication.

Mr. Valentin was a successful and painstaking teacher, and the fact that so many of the well-known chemists of this generation have received their early training from him, sufficiently indicates the value of his work; it would be difficult, indeed, to find one to whom the younger chemists of the present day are more indebted.

Within the last few weeks a few of his old friends and students of the Royal School of Mines had intended to present him with a testimonial; the efforts of the committee formed for this purpose will now be continued for the benefit of his widow and family.

\section{ELECTRIC LIGHTING}

$\mathrm{W}^{\mathrm{s}}$

need not insist on the extreme importance and interest of the exhibition which was opened last night at the Albert Hall, and for which extensive preparations have been making for some time. The public mind both in this country and abroad has been recently much agitated on the question of electric lighting, and, as night be expected, people are much confused among the many systems which have been brought forward, and even those who know something of the subject must find it difficult to make up their minds. Hence the importance of bringing together the various systems of electric lighting in such a way as to make comparison possible. It must, moreover, have an important educational influence upon the general public, helping somewhat to give them a truer idea of what physical science is, and what it is capable of doing for the good of mankind. The exhibition was opened last night by an able and interesting lecture by $\mathrm{Mr}$. W. $\mathrm{H}$. Preece, the chair being occupied by the Prince of Wales.

The machines to be exhibited are not only those which have been recently attracting attention, but also older ones, which will exhibit in an impressive manner the history of the development of electric lighting. Thus there are in the arena of the Albert Hall specimens of Mr. Holmes's original magneto-electric machine, and of the Alliance Company's magneto-electric machine, lent by Trinity House, as well as the Siemens dynamo machine and the Gramme machine, now so much in use for generating electricity for lighting and other purposes. There are also varieties of the Gramme and Siemens machines, differing from each other more in minute detail than in general principle.

The Jablochkoff and the Lontin systems are also strongly represented. From the centre of the dome depend five large lamps of the Siemens pattern, round the upper corridor are ranged the Jablochkoff lamps exhibited by the Société Générale d'Electricité, and around the arena stand handsome specimens of the Lontin lamp, mounted on tastefully-designed posts. The Wilde lamp will also be strongly represented. This may be briefly described as the Jablochkoff candle with the central non-conducting substance left out. In addition to a powerful Gramme machine, the British Electric Light Company exhibit several lamps, notably the Serrin, hardly yet surpassed in some points of excellence, the Werdermann, Reynier, Higgins, and Rapieff lights, and it is stated that the Anglo-American Electric Light Company will exhibit the Wallace and the Iridium Incandescent lights, the last-named of which is of much the same kind as that employed by Mr. Edison. The distinguishing characteristics of these various lights were explained by Mr. W. H. Preece, and the exhibition, which will remain open to the public for the remainder of the week, promises to be by far the most attractive display of scientific apparatus made for some considerable time past.

It may not be inappropriate to give here a short account of a new form of electric lighting, which, it would seem, will not be represented at the exhibition now opened at the Albert Hall.

At last week's meeting of the Paris Academy, $M$. Jamin presented a model of an electric light for which he claims the greatest possible simplicity. The two carbons are kept parallel by two insulated copper tubes, separated by an interval of two or three millimeters, in which they slide by friction, and which serve at once to direct them and to guide the current. They are surrounded by a directing circuit composed of five or six spirals coiled on a thin rectangular frame $40 \mathrm{~m}$. long and $15 \mathrm{~m}$. broad. This circuit, traversed by the same current as the carbons, and in the same direction, guides and fixes the electric arc at the extremity of the points. The lighting is effected automatically. For this purpose, the two extremities of the carbons are surrounded by a thin caoutchouc band which keeps them close together. Between them, a little above, a small fragment of iron wire is introduced, which keeps them in close communication by a single point. As soon as the circuit is closed, the current traverses this wire, makes it red-hot, and melts the caoutchouc; the two carbons, thus freed, separate, and the arc is established with a sort of explosion. Carbons of any size may be employed, up to $8 \mathrm{~mm}$. diameter. At this limit the waste scarcely exceeds $08 \mathrm{~m}$. per hour. By a proper arrangement the points may be maintained in their initial position. The apparatus may be suspended either with the points upwards or directed towards the ground. For several reasons, which Mr. Jamin states, the latter position is preferable. With its points downwards, then, M. Jamin claims for his light the following advantages:- $\mathrm{I}$. That of simplicity, since it requires no mechanism and no preliminary preparation; all is reduced to a support and to carbons ; (2) that of mechanical economy, since it succeeds in almost doubling the number of lights; (3) increase of illumination, since each of the new lights is nearly twice as powerful as the old; (4) quality of light, which is more white; (5) a more advantageous arrangement of the poles, which throw their greatest amount of light downwards, where it is required, instead of losing it towards the sky, where it is useless; (6) finally, economy of the combustible material, since the waste is less in proportion to the size of the carbons.

\section{NOTES}

WE greatly regret to announce the death at Rome, on April I4, of Prof. Paolo Volpicelli, the well-known Italian electrician. We hope to be able to give details of his life and work in an early number. 